\title{
Investigation of Relationship with Health Problems and Environmental Problems in the Silivri District of Istanbul
}

\author{
Ayşe Emel Önal ${ }^{1,2}$, Muharrem Köse ${ }^{2}$, Çiğdem Aslaner ${ }^{2}$, Hülya Gül ${ }^{1,2}$, Günay Güngör ${ }^{2}$ and Bilge Hapçığlu ${ }^{1,2}$ \\ 1. Center of Community Medicine Research and Application, the University of Istanbul, Istanbul Silivri 34570, Turkey \\ 2. Department of Public Health, the Medical Faculty of Istanbul, the University of Istanbul, Istanbul Fatih 34104, Turkey
}

\begin{abstract}
The purpose of this study is to investigate relationship between health and environmental problems in the district of Istanbul. This study is a cross-sectional questionnaire study that was conducted in the Silivri among the dates of 25th May-24th July, 2015. Questionnaires were conducted from 221 people living in Silivri with face to face interviews by researchers. Most of participants $(82.4 \%)$ thought the presence of hazardous environmental factors deteriorated their health $(\mathrm{n}=182)$. Water pollution $(48.4 \%, \mathrm{n}=107)$ and absence of free water $(50.7 \%, \mathrm{n}=112)$ were the most common complaints of the participants. Analyzing distribution of factors which disrupt health and history of chronic disease to urban and rural areas revealed more complaints about those factors and diseases in the rural areas than urban areas. The most common chronic diseases diagnosed were hypertension $(15.8 \%, \mathrm{n}=35)$, chronic lung diseases $(10.4 \%, \mathrm{n}=23)$, diabetes and coronary artery disease. Silivri people reported a lot of environmental problems which impair the public health. People living in villages close to industrial zone and seas which have marine pollution have more history of diseases and report more factors that negatively influence the health than people living in urban area.
\end{abstract}

Key words: Environment, pollution, health, chronic disease, prevention.

\section{Introduction}

It is the main duties of public health services to find out the health problems in a region, research the relation of these problems with environmental problems and help them solve $[1,2]$. When examining the major environmental issues in a residential area, water and waste management, air pollution, industry, energy production and consumption, the fuel used must be questioned. Water shortages and pollution can lead to various health problems, including infections. Air pollution cause respiratory disease and cardio-vascular diseases. Energy used can be related to water and food contamination and air pollution. Plants grown around thermal reactor lead, copper and zinc have been reported to be detected in high quantities [3]. There are eleven provinces in the Marmara region in Turkey. It is known that the

Corresponding author: Ayşe Emel Önal, Ph.D., main research field: environmental health.

This study was presented at 1 st International Conference on Environmental Science and Technology (ICOEST) in Sarajevo, Bosnia and Herzegovina, on September 9-13, 2015. priority environmental problem in seven provinces (Balıkesir, Bursa, Çanakkale, Edirne, Istanbul, Kirklareli and Tekirdağ) is water pollution. In other provinces of the Marmara region, waste problem (Bilecik, Sakarya and Yalova) and air pollution (Kocaeli) are the major environmental issues. Therefore, the most important environmental problem in the Marmara region is water pollution [4].

Silivri is a port town of Istanbul, located on the coast of Marmara sea. Although Silivri is a port town, the rate of population engaged in fishing is low. In Silivri, a large portion of the land is plain. Fifty-six percent of the agricultural land is in Istanbul. The main means of living is agriculture, stockbreeding, fishing and various industrial branches. There are more than three hundred enterprises engaged in industrial branches that may pose an environmental risk for the district. The main industries in the region are cement, petrol, metal industry, plastics, textile, dye, chemical substances, packaging and food. The share of the industrial sector of the economy in Silivri 
district is $29 \%$ [5]. The only company which is able to discharge waste water into the city sewage canal is $53 \%$ [6]. Waste waters in the region are discharged into sea from time to time. Also, there is a solid waste transfer station in the district. The population of Silivri is 161 thousand and 165 persons according to the data of Address-Based Population Registration System at the end of 2014. Fifty-four point three percent of the population are male and $45.67 \%$ of it are female. Twenty percent of them are under 15 years old, $72.3 \%$ are 15-64 years old, and over $7.7 \%$ are 65 years old [ 7 , 8]. The objective of this survey is to research the relation of the environmental problems with the health problems in Silivri district of Istanbul.

\section{Materials and Methods}

Silivri is a district in Istanbul, having a population of 161 thousand people, 22 neighborhood and 13 villages. Assuming that the chronic health problems of the public would be $15 \%$, the sample size was calculated to be minimum 196 at a confidence level of $95 \%$ and an error of $\pm \% 5$. The interview was made with 221 people over the age of 18 years. Five villages and five neighborhoods were selected by random sampling. Each village and neighborhood streets were selected by random sampling too. The interview was made with maximum 2 persons from one house along selected streets. The participants from villages and neighborhoods are engaged in the study on an equal basis. The villages are Çayırdere, Fenerköy, Kavakl1, Kurfallı and Akören, and the neighborhoods are Fatih, Alibey, Cumhuriyet, Mimarsinan and Yenimahalle $[9,10]$.

The survey was carried out between the dates of May 25 and July 24, 2015. Considering the environmental features found from the visits and observations in the region, the interview forms on the environmental problems and health problems was prepared. People in the sample were questioned about their jobs, health problems and environmental problems that they were aware based on face to face interview by the researchers and the nurses. The data were entered into
SPSS 21.0 packet program. For continuous variables, the mean standard deviation was calculated, and for discrete variables, the frequency and rate (\%) were calculated. In comparison of the groups, the chi-square test was used for discrete variables. The results were accepted to be at the confidence level of $95 \%$ and $p<0.05$ was accepted to be significant.

\section{Results and Discussion}

The average age of 221 participants was calculated as $45.86 \pm 15.71$. Forty-seven percent of the individuals were female and $53 \%$ were male. The average age of women was $43.31 \pm 14.62$ and the average age of men was $48.06 \pm 16.34$. Thirty-six point seven percent of participants were workers and $26 \%$ were housewives. The rate of farmers was $6 \%$. Workers mainly worked at the factory and food industry.

The participants' average period of living in Silivri was $34.79 \pm 21.75$ (min: 3 person, max: 82 person) years, while $91.5 \%$ of them lived in Silivri during summer and winter. When the participants were asked about the environmental features of the places close to where they live, the proximity to agricultural areas was found to be $64.7 \%(\mathrm{n}=143)$ and the coast was $33.9 \%(\mathrm{n}=75)$. The proximity to the industrial areas was very low in terms of settlement $(0.99 \%)$. They mainly grow wheat, sunflowers and watermelons as the agricultural product.

The question of "are there any factors in your environment that damage your health?" was answered by $82.4 \%(n=182)$ of the participants as 'yes'. Out of the factors listed in the questionnaire, the most damaging factors were as follows: expensive water $(50.7 \%, \mathrm{n}=112)$ and water pollution $(48.4 \%, \mathrm{n}=107)$. Comparatively, least damaging factors were the problem of heating $(1.8 \%, n=4)$ and the existence of dangerous wastes $(2.3 \%, \mathrm{n}=5)$. The Table 1 gives the rates of environmental problems reported by the participants and its distribution by gender.

When the distribution of health damaging factors in villages and districts is examined, it was seen that 
Table 1 Distribution of people reporting health damaging environmental factors by gender.

\begin{tabular}{|c|c|c|c|c|c|}
\hline \multirow{3}{*}{ Health damaging environmental factors } & & \multicolumn{4}{|c|}{ Gender } \\
\hline & & \multicolumn{2}{|c|}{ Female } & \multicolumn{2}{|c|}{ Male } \\
\hline & & $\mathrm{n}$ & $\%$ & $\mathrm{n}$ & $\%$ \\
\hline \multirow{2}{*}{ Water mercenaries } & No & 50 & 45.9 & 59 & 54.1 \\
\hline & Yes & 52 & 46.4 & 60 & 53.6 \\
\hline \multirow{2}{*}{ Frequent water cuts } & No & 97 & 45.8 & 115 & 54.2 \\
\hline & Yes & 5 & 55.6 & 4 & 44.4 \\
\hline \multirow{2}{*}{ Bad business environment } & No & 102 & 47.9 & 111 & 52.1 \\
\hline & Yes & 0 & 0.0 & 8 & 100.0 \\
\hline \multirow{2}{*}{ No sports field } & No & 90 & 44.1 & 114 & 55.9 \\
\hline & Yes & 12 & 70.6 & 5 & 29.4 \\
\hline \multirow{2}{*}{ Smoke } & No & 81 & 54.4 & 68 & 45.6 \\
\hline & Yes & 20 & 27.8 & 52 & 72.2 \\
\hline \multirow{2}{*}{ The stench of interest } & No & 75 & 42.6 & 101 & 57.4 \\
\hline & Yes & 27 & 60.0 & 18 & 40.0 \\
\hline \multirow{2}{*}{ Seawater dirty } & No & 64 & 40.0 & 96 & 60.0 \\
\hline & Yes & 38 & 62.3 & 23 & 37.7 \\
\hline \multirow{2}{*}{ There hazardous waste } & No & 99 & 46.0 & 116 & 54.0 \\
\hline & Yes & 4 & 66.7 & 2 & 33.3 \\
\hline \multirow{2}{*}{ There are factors distorting the overall health } & No & 19 & 48.7 & 20 & 51.3 \\
\hline & Yes & 83 & 45.6 & 99 & 54.4 \\
\hline
\end{tabular}

there were significantly more negative factors in the villages (chi-square $=10.862, \mathrm{p}=0.001)$. When the distribution of chronic disease histories in villages and districts, the chronic disease history of villagers was found to be significantly more than those living in the districts $(p=0,013$, chi-square $=6.185)$.

The distribution of environmental problems by village and neighborhood is given in the Table 2 . The distribution of health problems by village and neighborhood is given in the Table 3. And the distribution of health problems by gender is given in the Table 4.

When the participants were asked about various chronic health problems, the finding of hypertension came to the most $(15.8 \%, \mathrm{n}=35)$. While the rate of people suffering from chronic lung diseases such as asthma, chronic bronchitis or chronic obstructive pulmonary disease was $10.4 \%(n=23)$. In other respects, serious obesity and cancer were other health problems in this population $(2.3 \%, \mathrm{n}=5$ and $0.9 \%, \mathrm{n}=2$, respectively). The rate of those who reported that their children had a chronic disease was 3.6\%, $(\mathrm{n}=8)$.
When the potable water habits of participants were questioned, it was seen that they frequently used packaged potable water $(58.5 \%, \mathrm{n}=124)$. Fifty-seven point five percent of people $(n=46)$ engaged in agriculture used pesticide. When the people were questioned about their precautions against pesticide exposure, it was found that $82 \%$ of them used gloves, $76 \%$ used masks and $17 \%$ used overalls. When the health problems were compared by work done, the rate of health problems in housewives, retired people, farmers and unemployed people (students and freelancers) was found to be as high as statistically significant $\left(\chi^{2}=19.425\right.$, d.f $\left.=5, p=0.002\right)$. The average number of people living in the houses of participants was found to be $3.51 \pm 1.46$ (min: 1 person, max: 10 person), and 59.3\% $(\mathrm{n}=128)$ live in detached houses and $40.7 \%(n=88)$ live in apartments. When the participants were asked if they and their families have any health problems, $48.9 \%$ of them were found to have a disease history. Thirty-six point two percent of participants reported that they had chronic health problems. Any statistically significant 
Table 2 Distribution of people reporting health damaging environmental factors by settlement.

\begin{tabular}{llrrrr}
\hline \multirow{2}{*}{ Health damaging environmental factors } & & \multicolumn{3}{c}{ Settlement } \\
\cline { 3 - 6 } & & \multicolumn{3}{c}{ Village } & \multicolumn{3}{c}{ Neighborhood } \\
\cline { 3 - 6 } Water mercenaries & No & 56 & 51.4 & 53 & 48.6 \\
\hline \multirow{2}{*}{ Frequent water cuts } & Yes & 54 & 48.2 & 58 & 51.8 \\
\hline \multirow{2}{*}{ Bad business environment } & No & 107 & 50.5 & 105 & 49.5 \\
& Yes & 3 & 33.3 & 6 & 66.7 \\
\hline \multirow{2}{*}{ No sports field } & No & 105 & 49.3 & 108 & 50.7 \\
\hline \multirow{2}{*}{ Smoke } & Yes & 5 & 62.5 & 3 & 37.5 \\
\hline \multirow{2}{*}{ The stench of interest } & No & 105 & 51.5 & 99 & 48.5 \\
\hline \multirow{2}{*}{ Seawater dirty } & Yes & 5 & 29.4 & 12 & 70.6 \\
\hline \multirow{2}{*}{ There hazardous waste } & No & 74 & 49.7 & 75 & 50.3 \\
\hline \multirow{2}{*}{ There are factors distorting the overall health } & Yes & 36 & 50.0 & 36 & 50.0 \\
\hline & No & 82 & 46.6 & 94 & 53.4 \\
\hline & Yes & 28 & 62.2 & 17 & 37.8 \\
\hline
\end{tabular}

Table 3 Distribution of chronic diseases by gender.

\begin{tabular}{llrrrr}
\hline \multirow{2}{*}{ Chronic Diseases } & & \multicolumn{3}{c}{ Gender } \\
\cline { 3 - 6 } & & \multicolumn{1}{c}{ Female } & \multicolumn{2}{c}{ Male } \\
\cline { 3 - 6 } Hypertension & No & 86 & 46.2 & 100 & 53.8 \\
\hline \multirow{2}{*}{ Chronic lung disease } & Yes & 18 & 51.4 & 17 & 48.6 \\
\hline \multirow{2}{*}{ Diabetes } & No & 89 & 44.9 & 109 & 55.1 \\
& Yes & 13 & 56.5 & 10 & 43.5 \\
\hline \multirow{2}{*}{ Coronary artery disease } & No & 96 & 45.7 & 114 & 54.3 \\
& Yes & 6 & 54.5 & 5 & 45.5 \\
\multirow{2}{*}{ Obesity } & No & 98 & 46.9 & 111 & 53.1 \\
& Yes & 4 & 33.3 & 8 & 66.7 \\
\hline \multirow{2}{*}{ Cancer } & No & 99 & 45.8 & 117 & 54.2 \\
\hline \multirow{2}{*}{ Any chronic disease } & Yes & 4 & 80.0 & 1 & 20.0 \\
\hline
\end{tabular}

relation between the reported risks of environmental factors to health and disease histories could not be found $\left(\chi^{2}=3.531\right.$; d.f $\left.=1, p=0.06\right)$. However, 71 persons out of 80 having a chronic disease reported $(88.8 \%)$ that there were health damaging factors in their environment. People having a chronic lung disease reported smoking more than those who don't have. Likewise, people having hypertension reported the lack of sports hall and sea pollution more than those who don't have. Those having a coronary heart disease reported sea pollution and lack of potable water and smoking more than those who don't have. 
Table 4 Distribution of chronic diseases by settlement.

\begin{tabular}{|c|c|c|c|c|c|}
\hline \multirow{3}{*}{ Chronic Diseases } & & \multicolumn{4}{|c|}{ Settlement } \\
\hline & & \multicolumn{2}{|c|}{ Village } & \multicolumn{2}{|c|}{ Neighborhood } \\
\hline & & $\mathrm{n}$ & $\%$ & $\mathrm{n}$ & $\%$ \\
\hline \multirow{2}{*}{ Hypertension } & No & 85 & 45.7 & 101 & 54.3 \\
\hline & Yes & 24 & 68.6 & 11 & 31.4 \\
\hline \multirow{2}{*}{ Chronic lung disease } & No & 97 & 49.0 & 101 & 51.0 \\
\hline & Yes & 13 & 56.5 & 10 & 43.5 \\
\hline \multirow{2}{*}{ Diabetes } & No & 101 & 48.3 & 108 & 51.7 \\
\hline & Yes & 9 & 75.0 & 3 & 25.0 \\
\hline \multirow{2}{*}{ Coronary artery disease } & No & 104 & 49.5 & 106 & 50.5 \\
\hline & Yes & 6 & 54.5 & 5 & 45.5 \\
\hline \multirow{2}{*}{ Obesite } & No & 107 & 49.5 & 109 & 50.5 \\
\hline & Yes & 3 & 60.0 & 2 & 40.0 \\
\hline \multirow{2}{*}{ Cancer } & No & 109 & 49.8 & 110 & 50.2 \\
\hline & Yes & 1 & 50.0 & 1 & 50.0 \\
\hline \multirow{2}{*}{ Any chronic disease } & No & 59 & 41.8 & 82 & 58.2 \\
\hline & Yes & 51 & 63.8 & 29 & 36.3 \\
\hline
\end{tabular}

Those having diabetes reported more smoking than those who don't have. Those having obesity reported more poor working conditions than those who don't have. Also, those having cancer reported more sea pollution as environmental pollutants than those who don't have. As known, WHO was associated four non-communicable chronic diseases (diabetes, cancer, cardiovascular diseases and chronic respiratory diseases) with the risk factors such as tobacco use, physical inactivity, unhealthy diet and alcohol [11]. Silivri district is a port and fishing region, and the county has the highest agricultural production in Istanbul and also meets the need for fowls of the city by $87 \%$ [9]. In this survey, it was found that approximately $6 \%$ of the populations were farmers, $9 \%$ were officers and $37 \%$ were workers in various industrial branches. About $48 \%$ of people interviewed with were not doing an income generating job (housewives, students, unemployed or retired). Since quality of health is heavily depend on social and living conditions, chronic health problems obseved in unemployed people rather than employed. More than one third of the interviewers in the study group were the workers whose economic status was medium and low. On the other hand, in the study, people living in villages have more history of diseases than people living in urban area as in the research by Mitchell R. [12]. The industrial areas, solid waste transfer station and seas which have marine pollution close to these villages can be held responsible from this result. It is remarkable that people complain about dangerous wastes quite a little although there are more than three hundred industrial enterprises. This result makes people think that they are unconscious about it.

\section{Conclusions}

The results about environmental problems in this survey carried out in Silivri show that the majority of participants are aware of that there are health damaging factors in the environment. The most common diseases were hypertension, chronic lung diseases, diabetes, coronary artery disease, obesity and cancer. These diseases are diseases related to environmental issues as with lifestyle. The most frequently reported health damaging factors are the tap and potable water pollution and that water which is their basic requirement is very expensive. On the other hand, sea water pollution was also reported at a high rate. Usually, rural areas are reputed to be healthier than the cities, because of these areas giving people the opportunity to stay in touch with nature. 
But in the survey, it was seen that those living in the villages have significantly more disease histories than those living in the neighborhoods. And those living in the villages reported significantly healthier than those living in the neighborhoods. As industrial zone, livestock and agriculture related health risks could be led this situation.

In the region, approximately two-third of those engaged in agriculture use pesticide and most of pesticide users take precautions. Raising the awareness of people living in Silivri about the dangers of pesticide will further increase the safely use of pesticide. Elimination of health damaging factors, such as rehabilitation of tap water, sea water in order to be protected from diseases, increasing of the number of sports halls and raising the awareness of people about health will improve and enhance the public health. Other suggestions about environmental health are: (1) To prevent water pollution. Untreated domestic and industrial waste waters must be treated with appropriate technologies before discharged into receiving waters. It must be ensure that the pesticides and fertilizers are used at the right time with the proper amount. Nature should be prevented by ensuring proper disposal of spreading pesticide containers. The mixing of the sea and other surface waters of municipal solid waste should be avoided by ensuring regular store. Where the accumulation of animal excrement must be liquid sealed; (2) To prevent air pollution. It should avoid the use of poor quality fuel. Society should be encouraged to the use of environmentally friendly fuels and renewable energy sources (wind power has been used widely in Silivri); (3) To provide an effective waste management, it is necessary to reduce landfill waste by reusing and recycling, also increase the number of sanitary landfills and (4) In addition to all of these, it should be given awareness by training on environmental issues to the society.

\section{Acknowledgement}

The authors thank to Tülin Ataseven, Zehra Genç
Özkuk, Sema Araç Çallığulları, Zuhal Çorbacı Karagöz, Reyhan Meral İpekergil and Elif Gümüş due to contributions of interwievs of questionnaires.

This research was supported by the Istanbul University Scientific Research Project No. 56688 UDP project.

\section{References}

[1] Official Journal. 1983. "Environmental Law." Accessed January 20, 2015. http://www.mevzuat.gov. tr/MevzuatMetin/1.5.2872.pdf.

[2] Official Journal. 2013. "Istanbul University Community Medicine Research and Application Center Regulation." Accessed January 20, 2015. http://www.resmi-gazete. org/rega/istanbul-universitesi-toplum-hekimligi-uygulam a-ve-arastirma-merkezi-yonetmeligi-37893.htm.

[3] Association of Community Health Specialists (HASUDER). 2012. Environmental Health. Health Report of Turkey.

[4] Environment and Urban Ministry. 2014. "Environmental Problems and Priorities Evaluation." Accessed December 25, 2015. http://www.csb.gov.tr/db/ced/editordosya/ cevre_sorun_2014.pdf.

[5] Silivri Municipality. 2013. Silivri, Monografi a City. Istanbul: Mercek Publication.

[6] Silivri Municipality. 2012. "Environmental Protection and Control." Presented at Silivri County Manufacturing Industry Inventory.

[7] Turkish Statistical Institute. 2015. "TUIK, Popülation and Demographics." Accessed December 25, 2015. http://www.tuik.gov.tr/.

[8] Turkish Statistical Institute. 2013. Istanbul by Selected Indicators 2013. Ankara: Turkish Statistical Institute Press.

[9] Işıklar, Ö. 2014. "Silivri Municipality Activity Lecture for the Year 2014, İstanbul.” Accessed January 20, 2015. http://www.silivri.bel.tr/assets/uploads/files/faaliyetraporl ari/2014/index.html.

[10] Önal, A. E., 2015. “About Silivri District.” Accessed December 25, 2015. http://toplumhekimligi.istanbul.edu. tr/wp-content/uploads/2015/11/silivri-hakkinda.pdf.

[11] World Health Organization. 2008. “2008-2013 Action Plan for the Global Strategy for the Prevention and Control of Noncommunicable Diseases." Accessed December 25, 2015. http://apps.who.int/iris/bitstream/ 10665/44009/2/9789755903163 tur.pdf.

[12] Mitchell, R., and Popham, F. 2007. "Greenspace, Urbanity and Health: Relationships in England." $J$. Epidemiol Community Health 61: 681-683. 